\title{
EQUITABLE SHARING AND END USE OF NATURAL GAS
}

\author{
C. A. RAE*
}

\begin{abstract}
Pursuant to the Doctrine of Correlative Rights, an owner of property in an oil and gas pool is entitled to an opportunity to produce his just and equitable share of the oil and gas in the pool. If such an owner does not exercise this opportunity, this article concludes that the Rule of Capture is the law in Alberta, and the owner who is drained has no right under existing conservation legislation to limit the cummulative share of production of another owner in the pool. Natural gas has many uses in addition to its use as light and fuel. This article further submits, that under the provisions of the Alberta Oil and Gas Conservation Act, the Board has the power to regulate the end use of gas, and as such, could prohibit the use of natural gas in the manufacture of chemicals, fertilizers and carbon black.
\end{abstract}

This paper considers the role of conservation authorities in relation to the end use of natural gas and the power of such authorities to limit a lessee's cumulative share of production.

\section{A. RULE OF CAPTURE AND BOARD JURISDICTION}

By an order dated November 27, 1964, the Gas Utilities Board, on a referral from the Oil and Gas Conservation Board with respect to the Fort Saskatchewan Field, declared that it had no jurisdiction to order one producer to limit its total cumulative production from the pool, thereby leaving the other principal producer with the exclusive right to produce, when it pleased, the balance of the recoverable gas in the pool. ' The Gas Utilities Board did not give reasons for holding that it lacked jurisdiction in such a case, but such a ruling can be supported under the provisions of the Oil and Gas Conservation Act ${ }^{2}$ and the Gas Utilities Act. $^{3}$

Upon enactment, the provisions of the Oil and Gas Conservation Act and the Gas Utilities Act were added to and became a part of the laws of Alberta governing oil and gas development, ownership and production. The enabling legislation must be read in the overall context of the law as it existed at the time of the passage of the statutes, and interpreted so as not to take away or interfere with private rights or property unless it clearly and unambiguously intended to do so, and then only to the extent necessary to give effect to the legislation. This canon of construction is firmly established for interpreting statutes and powers delegated to administrative tribunals. ${ }^{\dagger}$ Perhaps the clearest statement of the rule is contained in the decision of the Supreme Court of Canada in British Columbia Electric Railway Co. Ltd. v. Public Utilities Commission." If anything, this rule of interpretation is more

- LL.B. (Dalhousie), LL.M. (Harvard). Barrister and Solicitor, Macleod, Dixon, Burns, Love, Leitch, Lomas, Charters and Montgomery, Calgary, Alberta.

1 The ruling by the Gas Utilities Board was as follows: "The Board considers that the application was quite properly referred to it by the Oil \& Gas Conservation Board. The Board is of the opinion, however, that it does not have jurisdiction to deal with the application."

2 S.A. 1957 , c. 63

3 S.A. 1960 , c. 37

4 See Halsbury's Laws of England, 3rd Ed.. Vol. 36. p. 413; Rex v. Hladych. (1942) 2 W.W.R. 230, at 234; Minister of Railways and Harbours of South Africav. Simmer, $\mid 1918$ A.C. 591, at 603; Spooner Oils Limited v. Turner Valley Gas Conservation Board [1933| S.C.R. 629, at 638 .

5 servation Board 1960$\}$ S.C.R. 837, at $845-46$. 
rigidly applied to the exercise of a discretion which the Legislature has left with an administrative tribunal. ${ }^{6}$

One of the proprietary rights which, subject to clear and unambiguous legislation to the contrary, a lessee acquires under an oil and gas lease is the right to produce from his lands oil and gas which, from time to time, is physically beneath such lands regardless of whether it was there initially or migrated there from his neighbour's lands. In Borys v. Canadian Pacific Railway, the Privy Council said:

If any of the three substances [gas, oil and water] is withdrawn from a portion of the property which does not belong to the appellant but lies within the same container and any oil or gas situated in his property thereby filters from it to the surrounding lands, admittedly he had no remedy. So, also, if any substance is withdrawn from his property, thereby causing any fugacious matter to enter his land, the surrounding owners have no remedy against him. The only safeguard is to be the first to get to work, in which case those who make the recovery become owners of the material which they withdrew from any well which is situated on their property or from which they have authority to draw. ${ }^{7}$

The law of capture enunciated by Lord Porter as being the common law in relation to ownership of oil and gas in Canada establishes that a producing mineral owner, or his lessee, may produce from wells on his lands all oil and gas from time to time under his lands. If such production results in drainage of oil or gas from his neighbour, he is not liable to his neighbour, and such dainage does not deprive his neighbour of any rights, as the neighbour does not own an indefeasible title to oil and gas in situ, but at most has a title subject to defeasance if there is drainage away from his lands. ${ }^{8}$ If at any given time there are 10 million cubic feet of gas in place under his lands, a mineral owner can not contend that he has the sole right to produce the said 10 million cubic feet. He has the opportunity, as an incident of his ownership of the mineral fee, to produce as much as he can in accordance with existing conservation regulations. His total production may be in excess of the said 10 million cubic feet of gas, or it may be below, depending on his rate of production, but he is not liable for any excess, nor does he have any claim for any deficit-this is simply an illustration of the rule of capture.

In the application relating to the Fort Saskatchewan field the principal applicant, Northwestern Utilities Limited, was a lessee-distributor of natural gas as was the other principal party.9 The Conservation Board had previously fixed allowables" for the wells in the field. It appears that Mid-Western Industrial Gas was producing its wells close to the allowables set by the Conservation Board, whereas North-

G See Schubert v. Sterling Trusts Corroration, (1943) 4 D.L.R. 584, at 591; Anderson v. Lacey, [1948] 2 W.W.R. 317, at 320; Frobisher Limited v. Oak, (1956) 20 W.W.R. 345, at $348-49$.

7 (1953) 7 W.W.R. (N.S.) 546, at 550

8 If the analogy with percolating waters is adopted fully, oll and gas in situ is not owned by any physical person (whether mineral owner or lessee) but becomes owned only when reduced to possession. See Lewis \& Thompson, Canadian Oil and Gas, Vol. 1. Div. A, Para 42-45. In Borys v. C.P.R., Ibid., Lord Porter assumed, for the purpose 1. Div. A, Para 42-45. In Borys v. C.P.R., Ibid., Lord Porter assumed, for the purpose being reduced to possession. Under each ownership theory the mineral owner has no remedy if there is drainage away from his lands and, accordingly, the rule of capture applies in each instance. The lessee under an oil and gas lease may not own the oil and gas in situ but only if, as and when it is piped and reduced to possession-see Berkheiser v. Berkheiser, [1957] S.C.R., 387.

9 Mid-Western Industrial Gas Ltd. A number of other parties intervened and filed submissions, including the City of Edmonton, Imperial Oil Limited, Pan American Petroleum Corporation. Sherrit Gordin Mines Limited, the Mid-Western Fort Saskatchewan Viking Gas Unit, and various royalty owners.

10 Oll and Gas Conservation Board Order No. GA34. 
western Utilities Limited was not, preferring instead to use its reserves in the field for peak load requirements. Northwestern Utilities Limited estimated that Mid-Western's total share of the reserves in the reservoir at the time of the application consisted of $\mathrm{XY}$ million cubic feet, and applied to the Gas Utilities Board for an order to the effect that when Mid-Western had produced XY million cubic feet it be prohibited from producing further. Such an order, if granted, would treat natural gas the same as coal and other hard minerals, so that a mineral owner would own and have the right to take only that which, at a given point in time, is under his land, and he could not drain from under his neighbour's land. If granted, the order would operate to nullify completely the rule of capture.

The provisions of the Oil and Gas Conservation Act which may have some bearing on the jurisdiction of the Board in such an application are Sections 2(t), $2(u), 4,17,34(w), 35(1)(d)$ and $36(2)$. Sections $2(t)$ and $2(u)$ define "waste" and "wasteful operations". Section 4 defines the intent and purpose of the Act and Sections 17, 34 (w), $35(1)(d)$ and 36 (2) confer certain powers on the Board. The applicable provisions of the empowering legislation are as follows:

17. The Board, with the approval of the Lieutenant Governor in Council, may make such just and reasonable orders and directions as the Board deems requisite to effect the intent and purpose of this Act and as are not otherwise specifically authorized by this Act.

34. The Lieutenant Governor in Council, upon the recommendation of the Board, may make general regulations or special orders

(w) generally to conserve oil and gas, and to prevent waste or improvident disposition thereof, and to do any other matter reasonably incidental to the development and drilling of any oil or gas wells, the operation thereof, and the production therefrom.

35. (1) The Board may, by general or special orders,

(d) control and regulate the production of oil, gas and water by restriction, proration or prohibition.

36.(2) The Board, with the approval of the Lieutenant Governor in Council, may, by general or special orders, restrict the amount of oil or gas or both that may be produced from a pool within the Province

(a) by limiting, if such limitation appears necessary, the total amount of gas that may be produced from the pool, having regard to the efficient use of gas for the production of oil, and to the demand for gas from the pool, and

(b) by distributing the amount of gas that may be produced from the pool in an equitable manner among the wells in the pool, for the purpose of giving each well owner the opportunity of producing or receiving his share of the gas in the pool.

The principal question is whether by the provisions above quoted, the legislature has clearly and unambiguously changed the law of capture, by empowering the Board to give an order stating that a designated person can produce a cumulative total of $\mathrm{XY}$ million cubic feet of gas and no more from a pool, thereby leaving the balance of the recoverable reserves to be taken by other owners.

Sections 17 and $34(w)$ are the type of catch-all sections nearly always found in statutes which confer powers upon administrative tribunals. Such general clauses are never interpreted to give to the administrative tribunal the power to destroy private rights without compensation.

By legislation such as Sections 17 and $34(w)$, the legislature is in 
effect saying "we have specifically granted in this Act the special powers needed to effect the purpose of the Act, but in the event that some minor or ancillary power has been overlooked, we grant the same by these general sections". The legislature can hardly be said to have gone to the trouble of prescribing in clear and express language the many minor powers dealt with in the Oil \& Gas Conservation Act and in the Gas Utilties Act with the intention that the Board have, by such general provisions as Section 17 and $34(w)$, the much more important power to restrict the cumulative production of gas from specific lands.

The power to prevent a mineral owner from drilling on any part of his land that he chooses is clearly much less important than the power to restrict the total cumulative production from those lands. It should be noted, however, that the power to prescribe the exact location of the well is clearly set out in Section 34 (c). This, together with the many similar examples found in the Oil \& Gas Conservation Act and in the Gas Utilities Act, suggests that fundamental and important proprietary rights are not intended to be affected or altered in cases where the only empowering legislative provisions are the blanket provisions of Sections 17 and $34(w)$ or similar sections.

Sections 35 (1) (d) also contains very general words which, in light of judicial decisions, cannot be used to take away the legitimate and valuable right of capture, as such words are reasonably capable of being construed to avoid this result," nor does the language of Section 35 (1) (d) require that construction. ${ }^{12}$ Plainly, the Oil and Gas Conservation Board can "control or regulate the production of oil, gas and water by restriction, proration or prohibition", without limiting the cumulative production and can thereby given meaning and effect to all of the words in Section 35(1)(d) without confiscating the proprietary right of capture.

Reference has also been made to Section 36(2) of the Oil \& Gas Conservation Act, which empowers the Board to restrict the amount of gas that may be produced from a pool and distribute the same in an equitable manner among the various wells in the pool for the purpose of giving each well owner the opportunity of producing or receiving his share of the gas in the pool. It should be noted that the Section refers to production rather than to in situ reserves, and to the distribution of that production among the owners of the various wells in the pool. The Board can give effect to this Section by determining allowables for the various wells in the field and thereby conferring upon the well owners the opportunity to take their fair share of gas production from the pool. The power to provide an opportunity, by fixing well spacing and well allowables, to each owner to share in the gas produced, does not extend to giving that owner the right to produce, when he pleases, a volume which is estimated to be under his lands, which said right would be a guarantee of production and reserves, rather than the provision of an opportunity to share in production from the pool. If the legislature had intended to empower the Board under Section 36 (2)

11 Minister of Railways v. Simmer, Surra, n. 4.

12 Spooner Oits Limited v. Turner Valley Gas Conservation Board, Supra., n. 4. 
to provide such a guarantee, rather than the mere opportunity, it could have specifically so specified in Section $36(2) .^{13}$

Section 4 of the Oil \& Gas Conservation Act outlines the objects of the Statute, and in Subsection (d) refers to affording to each owner the opportunity of obtaining his just and equitable share of production of any pool. Section 4 is not, however, an empowering section and cannot be used to confer on the Board a power which cannot be brought within another section of the Act.

If an owner of wells on Tract A produces his wells at their capacity or at their allowable, and this causes drainage from Tract B to Tract A, the owner of Tract B is not unjustly or inequitably treated. The terms "unjust" and "inequitable" suggest a deprivation of a right or privilege, but with the rule of capture being an incident of the title to Tract $B$, there is, by drainage from Tract $B$ to Tract $A$, no deprivation of a right or privilege, as the title to Tract $B$ oil and gas is subject to defeasance by drainage to Tract $A$-an essential characteristic of the ownership of the estate.

As the law of capture applies in Alberta, the lessee of Tract B knows or is considered to know that he has no complaint if drainage away from his Tract to Tract A occurs, and he is obligated, if he wishes to prevent drainage, to produce from Tract $B$. If the owner of Tract $B$ is given the opportunity, but prefers not to produce from Tract $B$, how can it be said that it is not just and equitable for the owner of Tract $A$ to drain Tract $B$ ?

If an order is given limiting the cumulative volume of gas produced from Tract $A$, this confers on the owner of Tract $B$ new and additional rights, and deprives the owner of Tract $A$ of rights or privileges. Looked at in this way, Section 4 (d) and the empowering provisions of Section 36 (2) are merely restatements of the rule of capture, which provides that an owner's just and equitable share is that which he can get, regardless of drainage, and in futherance of the objects of Section 4, the Act should be construed so as to afford each party the opportunity to acquire its just and equitable share, being that share which flows as an incident of his title to oil and gas in place-catch as catch can.

Wherever the legislature has intended that the Oil \& Gas Conservation Board, the Public Utilities Board or the Gas Utilities Board have the power to affect proprietary rights it has expressely said so. For example, Sections 42, 43 and 43a of the Oil \& Gas Conservation Act clearly and expressly authorize the Oil and Gas Conservation Board to grant orders affecting the proprietary right to refuse to carry or purchase gas or oil, and Section 6 of the Gas Utilities Act expressly and clearly authorizes the Public Utilities Board to affect the proprietary right to charge what the market will bear for one's gas. If the legislature had intended the Oil \& Gas Conservation Board, the Public Utilities Board or the Gas Utilities Board to have the power to destroy the proprietary right of capture by granting an order limiting the total cumulative production of gas from a lessee's land in a pool, it would have said so in as clear and

13 To issue such an order under Sections 17,34 or 36 would be akin to compulsory unitization, and it is significant that the empowering legislation relating to compulsory unitization has not. as yet, been proclaimed. 
express language as it has done in other instances where one or more of these Boards have the power to affect proprietary rights. ${ }^{14}$

Orders fixing total cumulative production of one of the owners of oil and gas in a pool, not being within any empowering Section of the applicable statutes, and being outside the general purpose and intent of the legislation, cannot therefore be validly issued by the Oil \& Gas Conservation Board, the Gas Utilities Board or the Public Utilities Board of Alberta. ${ }^{15}$

\section{B. END USE OF GAS}

Some early American decisions held that a mineral owner is entitled to reduce the gas to possession and thereafter to sell, to use, to give away, or to squander the same. ${ }^{16}$ More recent American decisions have established, as one of the correlative rights of owners of a common reservoir, the right to restrain any owner from wasting extracted substances. ${ }^{17}$ If the extracted substance is used for some economic purpose, the courts may not be prepared to interfere with such use, even if it is established that the substance could be put to a greater economic use. ${ }^{\text {is }}$

The following provisions of the Alberta Oil and Gas Conservation Act are relevant with respect to the problem of regulating the end use of gas, ${ }^{10}$ namely:

34. The Lieutenant Governor in Council, upon the recommendation of the

Board, may muke general regulations or special orders

(w) generally to conserve oil and gas, and to prevent waste or improvident disposition thereof, and to do any other matter reasonably incidental to the development and drilling of any oil or gas wells, the operation thereof, and the production therefrom.

2. In this Act,

(t) "waste", in addition to its ordinary meaning, means "waste" as that term is understood in the oil and gas industry, and includes the underground or surface loss through wasteful operations of oil or gas or of potentially recoverable oil or gas;

(u) wasteful operations means

(viii) the use of gas for purposes other than pressuring, cycling, pressure maintenance or for light or as fuel, unless such use is beneficial, in the public interest and efficient.

45.(1) No person shall, within the Province, use or consume, for a purpose other than

(a) for pressuring, cycling or pressure maintenance, or

(b) for light or as fuel,

gas produced in the Province, until he has filed with the Board particulars concerning such use or consumption in such detail as the Board may require.

14 Such a clear and unambiguous expression may exist when the provisions relating to compulsory unitization are proclaimed, as these secticns relate to reserves in situ and not merely the sharing of actual production.

15 The Boards may have power to affect the rule of capture by issuing orders limiting total production from the entire pool for such purposes as engineering safety and
reservoir pressure, but should not, under the guise of such purposes, limit Tract A's production so that under no circumstances will Tract $B$ be drained-as envisaged by the applicable statutes this is not a function of conservation.

10 Hague v. Wheeler, $157 \mathrm{~Pa}$. 324. (1893), is considered to be the leading case. See Williams and Myers, Oil and Gas Law, Vol. 1, Para 204-6.

17 Kuntz, Correlative Rights in Oil and Gas, (1958) 30 Miss. L.J. 1: Louisville Gas Co. v. Kentucky Heating Co., $117 \mathrm{Ky}, 71,77$ S.W. 368 (1903). and Manufacturer's Gas \& Oil Co. v. Indiana Natural Gas \& Oil Co., 155 ind. App. 461.57 N.E. 912 (1900). \& right may be available to an interested party under this common law rule apart from legislative provisions dealing with conservation and waste.

18 See Williams \& Myers, Supra, n. 16. This function is perhaps better handled by an administrative body which considers overall public policy and need.

10 If the gas is exported from the producing province, the regulatory authorities of that province may not have the power, under the British North America Act, 30 \& 31 Victoria c. 3, to prohibit export or regulate the end use. See Lewis \& Thompson, Canadian Oil and Gas, Vol. 7. Div. A.. Para. 174; Spooner Oils Ltd. v. Turner Valley Gas Conservation, Board, i1937) S.C.R. 629; Mercury Oils Ltd. v. Vulcan-Brown Petroleums Ltd., [1943] S.C.R. 37, and Reference re The Farm Products Marketing Act [19;7] S.C.R. 198. 
(2) Where a person uses or consumes gas or proposes to use or consume gas for a purpose such that he is required to file particulars under subsection (1), the Board may order the person to so use or consume the gas that there is no waste.

Section $34(w)$ refers to prevention of waste or improvident disposition of oil and gas. The definition of wasteful operations specifies that to use gas for a purpose other than for pressuring, cycling, pressure maintenance or for light or as fuel is a wasteful operation, unless such use is beneficial, in the public interest and efficient. The use of gas for the purpose of light or as fuel is by definition not a wasteful operation, and the Board could not issue an order prohibiting the use of gas for light or fuel under that portion of Section $34(w)$ relating to the prevention of waste.

The term "improvident disposition of gas", used in Section $34(\mathrm{w})$ is, however, wider in its scope. The term "improvident" is defined as "unforeseeing, heedless or thriftless," issue orders, if it in good faith determines that a use of gas, even as fuel or light, is not the best economic use of the substance."1 If Section $34(w)$ is taken literally and read in conjunction with clauses $2(u)$ and $2(t)$, it might be said that the use of gas in the manufacture of chemicals and fertilizers is a wasteful operation-it may be a provident disposition, but it is, by definition, waste, unless beneficial, in the public interest and efficient, and Section $34(w)$ is disjunctive rather than conjunctive. ${ }^{22}$

If the Board has the power to prohibit the use of gas in the manufacture of chemicals, fertilizers and carbon black, this power could, it seems, be exercised at any time, and theoretically, established plants and businesses could be closed down through the lack of a source of supply of petrochemical feed stocks. A number of manufacturing operations require the investment of large sums of money, and provision should be made whereby a potential user could apply to the Oil \& Gas Conservation Board, or some other agency, for an order approving the proposed use, which order, once granted, would not be subject to reversal or suspension, except in times of war or national emergency.

The Board in considering the question as to whether the end use of gas constitutes waste or is an improvident disposition, must have regard to numerous factors involving economics, politics and social considerations, as the use of gas in a labour intensive industry in a depressed area may be provident, when all relevant factors are considered, but would be improvident if one looked only at the end use of the gas in vacuum.

20 Shorter Oxford English Dictionary, Vol 1.

21 The right to challenge the Board's conclusions as to what is or is not an improvident disposition may be limited, as it is subject to all of the rules relating to appeals from administrative tribunals.

22 It might be argued that in order to come within the provisions of Section $34(w)$. the improvidence must be in the disposition by the producer rather than in the use of the gas by the buyer, in which event the only factor to be considered is the price received. One cannot look to section 4 for assistance in a case where the use is as fuel or light, as this use, by definition, is not a wasteful operation and hence not within the ambit of Section 4(b) providing for the prevention of waste of the gas resources of the Province. If the provisions of Section $34(w)$ are disjunctive, and some patriotic homeowner wishes to conserve all gas for use in the future as light or fuel, the Board may, by virtue of the definition of wasteful operations, be accused of refusing to exercise its jurisdiction, if it refuses, on an appropriate application, to issue an order prohibiting the use of gas for the manufacture of chemicals, as such use while provident is a wasteful operation unless it is determined that such use is beneficial, in the public interest and efficient. 